\title{
THE EFFECTIVENESS OF CRIMINAL LAW POLICIES ON RELIGIOUS ABUSE AND BLASPHEMY CRIMES
}

\author{
Yudhi Achmad Bashori, M.H.I. \\ IAIN Ponorogo, Indonesia \\ yudhiab@iainponorogo.ac.id
}

\begin{abstract}
Criminal law policy is one of the instruments of the rule of law - specifically Indonesia - to realize security and order in the lives of every citizen. One of the crimes that often trigger conflicts between the communities is acts related to religion. This is because anthropologically, Indonesian communitiesare known as religious communities. So that if there is an "offended religious" as a consequence of someone's action, it often leads to mass actions. This article focuses on 2 formulations; they are: how is the criminal law policy on religious abuse and blasphemy in Indonesia? How is the effectiveness of criminal law policy on religious abuse and blasphemy in Indonesia?

Methodologically, this article uses a qualitative method that will compare existing law policies with Soerjono Soekanto's theory about factors that influence law enforcement. The data source is taken from several applicable laws, news media, and a descriptive analysis of the author.

In conclusion, the government has issued a law policy in the form of ratification of Law no. 1 PNPS of 1965 concerning the Prevention ofReligious Abuse and or Blasphemy. At the same time, the effectiveness of criminal law policies against Religious Abuse and Blasphemy (PPA) criminal acts is considered very useful. However, there are deficiencies in the law awareness factor among the community, which in the practice of law enforcement often results in acts of anarchism that violate other legal instruments.
\end{abstract}

\section{Keywords: law, religious abuse, blasphemy, criminal law policy}

\section{A. INTRODUCTION}

Religion in the history of national and state life in various parts of the world has proved to play an important role. The recognition of religious freedom proves this as one of the human rights that are non-derogable rights. ${ }^{1}$ The definition of the nature of this right is that the right stated explicitly in the human rights convention is a right that cannot be fulfilled by the state in any circumstances and conditions, including during

\footnotetext{
${ }^{1}$ Recognition of the right to religious freedom by the international community is contained in various international legal instruments such as conventions, declarations, and others. Among international legal instruments that are often referred to as human rights is the Universal Declaration of Human Rights. International Covenant of Civil and Political Rights, also International Convention on the Elimination of All Forms of Racial Discrimination.
} 
dangerous situations such as civil war or military invasion. Through this acknowledgment, it can be interpreted that everyone has the same right to embrace religion in accordance with their beliefs.

Indonesia, as a country based on Believe in $\mathrm{God}^{2}$, also explicitly acknowledges this right to freedom of religion. This right is stated in the country's constitution (1945 Constitution), which states that the state guarantees the freedom of every citizen to embrace religion. ${ }^{3}$

However, over time, several incidents have arisen which are closely related to the right to freedom of religion. These various events were able to attract the attention of the community and ultimately lead to pros and cons. The events referred to in this matter include the Abuse and Blasphemy of Religion.

In the law system in Indonesia, acts of Religious Abuse and Blasphemy are included in criminal acts. This has the consequence that anyone who commits the crime will be punished based on a court decision.

Even though it has officially been a criminal offense, the act of the Religious Abuse and Blasphemy of Religion (hereinafter written by PPA) is seen by some parties as not an act which is categorized as an unlawful act. According to them, because this is included in the realm of beliefs, the state has no right to interfere in the private affairs of citizens. Even the state should protect this action because it is included in the area of human rights.

Although the debate on this matter continues to occur, it must still be recognized by all parties that the law must continue. Along with that, this paper was prepared to examine the effectiveness of criminal law on criminal acts of religious abuse and blasphemy in Indonesia.

\section{B. DISCUSSION}

\section{Criminal Law Policy}

\footnotetext{
${ }^{2}$ The Constitution of the Republic of Indonesia of 1945 Article 29 Verse 1

${ }^{3}$ The Constitution of the Republic of Indonesia of 1945 Article 29 Verse 2
} 
Crime is a common thing that humans encounter in interactions with other humans. By various conflicting interests often lead to crime and ultimately cause harm to the other party.

As the loss occurring, the peace and tranquility that is the desire of citizens (public interest) will be reduced so that the state intervenes to eliminate or at least reduce the impact felt by the people from these actions. ${ }^{4}$

Criminal law policies is one of the methods used by the state in dealing with crime. Criminal law policycan be briefly interpreted as a "crime prevention policy using criminal law."

As quoted by Saiful Abdullah in his thesis, G P. Hoefnagels outlines several efforts to tackle crime:
a) Criminal law application
b) Prevention without punishment
c) Influencing views of society on crime and punishment/ mass media ${ }^{5}$

By the opinion of Hoefnagels above, crime prevention efforts (including PAA) that occur in the community can be pursued through 2 (two) types of approaches, namely penalties (through criminal law processes) and nonpenalties (without going through criminal law processes). Both functions must go hand in hand in harmony and complete each other.

If the first approach is taken, then this means that crime prevention is carried out using a criminal law policy (penal policy / strafrechtenpolitiek), that is, "efforts to realize criminal legislation in accordance with the circumstances and situation at a time and for the future. " That is, criminal law functioned as social control, with sanctions in the form of a crime to be used as a means to resolvethe crime. Thus it is expected that social norms can be enforced with

4 Henny Nuraeny, Tindak Pidana Perdagangan Orang: Kebijakan Hukum Pidana dan Pencegahannya (Jakarta: Sinar Grafika, 2013) page 48.

${ }^{5}$ Barda Nawawi Arief, Bunga Rampai Kebijakan Hukum Pidana dalam Saiful Abdullah. Kebijakan Hukum Pidana (Penal) dan Non Hukum Pidana (Non Penal) dalam Menanggulangi Aliran Sesat. Thesis. (Semarang :University of Diponegoro, 2008), Page 28. 
sanctions held by criminal law against someone who behaves not in accordance with these norms. ${ }^{6}$

On the other hand, criminal prevention above is also part of law enforcement efforts. Therefore it is often said that politics or criminal law policy is an integral part of social politics (social policy). According to BardaNawawiArief, as quoted by Henny Nuraeni, social policy is a reasonable effort to achieve community welfare and community protection. ${ }^{7}$

Regarding PPA crime, the state in applying criminal law has several law instruments that are used to ensnare PAA criminal offenders. The law instruments are:

a) Criminal law code (KUHP)

b) PNPS Law No. 1 of 1965 concerning Prevention Religious Abuse and / or Blasphemy of Religion.

\section{Effectiveness of Law}

As it is known that a law is not always conceptualized as the law is what it is in the book, but also empirically conceptualized as law as what is (functioning) in society. In other words, the law no longer stands as norms that exist exclusively in a formal legitimacy, but rather is an empirical phenomenon that has been observed in experience. In terms of substance, the law is seen as a real social force in society and empirical form, which works with results: effective or ineffective. ${ }^{8}$

In assessing the effectiveness of the law, according to SoerjonoSoekanto as quoted by Imam Sukadi, it can be seen from several factors that influence the operation of law or law enforcement:

a) Law or legislation

\footnotetext{
${ }^{6}$ Barda Nawawi Arief, Bunga Rampai Kebijakan Hukum Pidana. Page 29

${ }^{7}$ Henny Nuraeny, Tindak Pidana Perdagangan Orang. Page 48-49

${ }^{8}$ Aan Andrianih. Efektivitas Undang-Undang No. 1 Tahun 1965 tentang Pencegahan Penyalahgunaan dan Penodaan Agama terhadap Kerukunan Beragama. Thesis. (Jakarta: University of
} Indonesia, 2012), page 11-12 

b) Law enforcer
c) Facilities that support law enforcement
d) Society law awareness
e) Culture $^{9}$

By the parameters above, the effectiveness of law enforcement for PPA crime can be assessed.

\section{Criminal Law Policies of Religious Abuse and Blapshemy Crimes in Indonesia}

As has been explained before, that between the efforts to overcome crime and the perpetrators. This effort is certainly in accordance with the form of the Indonesian state, which is a state of law (rechtstaat).

Regarding religious offenses ${ }^{10}$ in the criminal law system in Indonesia, basically, there is no special chapter on religious offenses in the Criminal Code (KUHP), which is used as the primary source of criminal law in Indonesia. This is different when compared to other offenses that clearly exist, such as murder, theft, fraud, and others. However, there are a number of offenses that can actually be categorized as part of religious offenses:

a) Obstructing religious gatherings that are public and permitted, or permitted religious ceremonies, or burial ceremonies. ${ }^{11}$

b) Interfering public and permissible religious gatherings, or permitted religious ceremonies or burial ceremonies, by causing riots or noise. ${ }^{12}$

c) Laughing at a religious official in carrying out his permitted duties. ${ }^{13}$

${ }^{9}$ Soerjono Soekanto. Faktor-Faktor yang Mempengaruhi Penegakan Hukum dalam Imam Sukadi. Matinya Hukum Dalam Proses PenegakanHukum di Indonesia. Jurnal Risalah Hukum. Vol. 7 No. 1, 2011, page 42

${ }^{10}$ Offense as quoted by D. Simons is behavior that is threatened with crime, is against the law related to mistakes and is carried out by someone who is capable of being responsible. See Andi Hamzah. Terminologi Hukum Pidana. (Jakarta: Sinar Gragika. 2013), Page 48. Religious offenses which means regarding to religion.

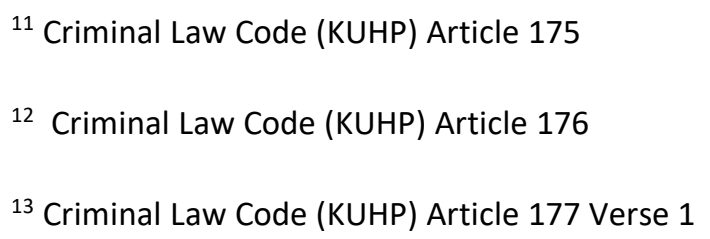


d) Insulting objects for worship purposes on the spot or at the time of worship carrying out. ${ }^{14}$

e) Making noise near buildings to perform permitted worship or for a court hearing, when there is worship or a hearing. ${ }^{15}$

Whereas relating to PAA criminal offenses, the regulation of sanctions for those criminal offenses has only been enacted since the enactment of Law No. 1 PNPS of 1965 concerning Prevention of ReligiousAbuse and or Blasphemy of Religion. Before becoming a law, the regulations signed during the Soekarno's presidency were initially only in the form of a Presidential Decree. ${ }^{16}$ Then with the passing of Law No. 5 of 1969 made many Presidential Regulations and Stipulations changed into Laws. ${ }^{17}$

In Law No. 1 PNPS of 1965 concerning Prevention of Religious Abuse and / or Blasphemy of Religion (hereinafter written Law No. 1 / PNPS / 1965), the religious offenses contained therein expressly prohibit Indonesian citizens from engaging in the religious abuse and desecration of religion.

In Article 1, it states :

Setiap orang dilarang dengan sengaja di muka umum menceritakan, menganjurkan atau mengusahakan dukungan umum, untuk melakukan penafsiran tentang sesuatu agama yang dianut di Indonesia atau melakukan kegiatan-kegiatan keagamaan yang menyerupai kegiatan-kegiatan keagamaan dari agama itu, penafsiran dan kegiatan mana menyimpang dari pokok-pokok ajaran agama itu.

Translation :

Every person is forbidden to deliberately publicly tell, encourage or seek public support, to make an interpretation of a religion held in

\footnotetext{
${ }^{14}$ Criminal Law Code (KUHP) Article 177 Verse 2

${ }^{15}$ Criminal Law Code (KUHP) Article 503 Verse 2

${ }^{16}$ This Presidential Decree was signed by President Soekarno on January 27, 1965.
}

17 See Law No.5, 1969 about Pernyataan Berbagai Penetapan Presiden Dan Peraturan Presiden Sebagai Undang-Undang (Statements of Presidential Decrees and Presidential Regulations as Laws). This law was passed on July 5, 1969 during the Soeharto era. As the implementing regulations for this Act, PP No. 28 of 1969. The word "PNPS" in Law No. 1 / PNPS 1965 above comes from "Presidential Decree". Whereas the Act which contained the word "PRPS" previously was "Presidential Regulation". 
Indonesia or carry out religious activities that resemble the religious activities of that religion, interpretation, and activities which deviate from the main points the principal teachings of that religion.

Then in the next article (Article 2), it is explained that the party committing the violation of article 1 will be given an order and a stern warning to stop the activity based on a Joint Decree (SKB) between the Minister of Religion, the Attorney General and the Minister of Home Affairs. Even if the violation is committed by an organization or a group of faith, the President can dissolve it based on the considerations of the Minister of Religion, Attorney General and Minister of Home Affairs. If the violation continues after the warning is given, then the adherent or the management of the organization in question can be sentenced to a maximum imprisonment of 5 (five) years. $^{18}$

Then in this Law there is also an article (article 4) which was established to add a new criminal article in the Criminal Code that is article 156a. This Article reads:

Dipidana dengan pidana penjara selama-lamanya lima tahun barangsiapa dengan sengaja di muka umum mengeluarkan perasaan atau melakukan perbuatan:

a. yang pada pokoknya bersifat permusuhan, penyalahgunaan atau penodaan terhadap suatu agama yang dianut di Indonesia;

b. dengan maksud agar supaya orang tidak menganut agama apa pun juga, yang bersendikan ke-Tuhanan Yang Maha Esa.

Translation :

Convicted of imprisonment for up to five years, whoever deliberately publicly issues or acts:

a. Which is basically hostility, abuse or blasphemy of a religion that is adopted in Indonesia;

b. As the intention that people do not follow any religion, which is based on God.

When compared to the contents in article 1 and article 4 of Law no. 1 / PNPS / 1965, there are similarities and differences. The similarity lies in the imposition of a

${ }^{18}$ Law N0.1 PNPS, 1965 Article 2 and 3 
maximum sentence of 5 (five) years in prison. At the same time, the differences that occur are substantial and procedural. It is called a substantial difference because, in article 1 , it is an article containing religious perversion offenses, while article 4 (156a of the Criminal Law Code) contains anti-religious offenses. The so-called procedural differences because article 1 requires a warning (in the presence of the Joint Decree), while article 4 (156a of the Criminal Code) does not require a warning. The differences and similarities of the two articles above can be seen in the following chart:

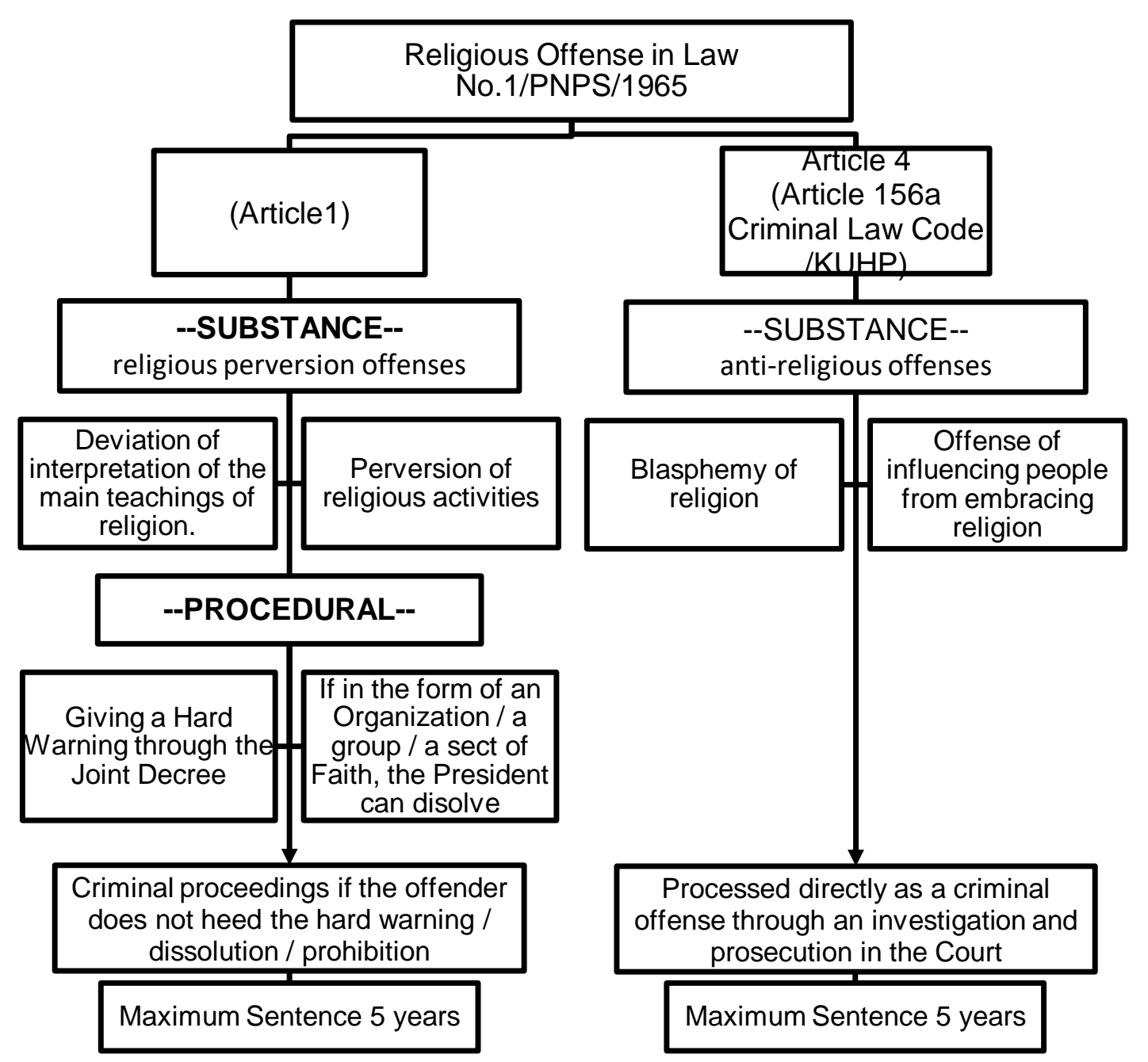

Further explanation and elaboration on the meaning of the term "Penyalahgunaan (Tr. Religious Abuse)", "Blasphemy" is indeed not found either in the Law above or in the Criminal Code. According to the Big Indonesian Dictionary, the word "Penyalahgunaan (Tr: Religious Abuse)" means the process, method, act of 
abuse, misappropriation. This word comes from the word of misuse, which means to do something not as it should; perverted. ${ }^{19}$ According to Riries WU, acts that are in the form of misuse of religion are physical acts concerning a religion thatis generally regarded by people as followers of the religion concerned as abusing the religion - for example, asking for donations to benefactors on the grounds of building a place of worship, on matters for his personal interests.According to Riries WU, acts that are religiously abusive are physical acts concerning a religion thatis generally regarded by the people of the religion as being misused/abuse-for example, asking for donations to benefactors by having a reason to build a place of worship, while the real reason is for his personal interests. ${ }^{20}$-Meanwhile, according to FachrizalAfandi, an explanation of this term can be referred to as article $1 .{ }^{21}$ Further on the explanation of article 2 of Law No. 1 / PNPS / 1965 stated that:

"Sesuai dengan kepribadian Indonesia, maka terhadap orang-orang ataupun penganut-penganut sesuatu aliran kepercayaan maupun anggota atau anggota pengurus organisasi yang melanggar larangan tersebut dalam pasal 1, untuk permulaannya dirasa cukup di beri nasehat seperlunya. Apabila penyelewengan itu dilakukan oleh organisasi atau penganut-penganut aliran kepercayaan yang mempunyai efek cukup serius bagi masyarakat yang beragama...."

Translation:

"In accordance with the personality of Indonesia, then to people or adherents something faiths and members or leading members of the

\footnotetext{
${ }^{19}$ Indonesia Dictionary (KBBI) Offline versi 1.5

${ }^{20}$ Riries Widhi Utomo. Analisa Hukum Pidana Terhadap Tindak Pidana Penistaan Agama Di Indonesia (Kasus Penistaan Agama Pendeta Antonius Rechmon Bawengan Di Temanggung Jawa Tengah). Skripsi. (Semarang: IKIP PGRI, 2014), Page 15.

${ }^{21}$ Fachrizal Afandi. PAKEM: Salah Satu Upaya Negara dalam Melindungi Agama. Journal AlQanun. Vol. 12 No. 2, 2009, Page 489-490.
} 
organization who violate the prohibition in Article 1, for the beginning it is enough given the necessary advice. If the deviation is carried out by organizations or adherents of a belief that has serious effects on religious communities ..."

So the author agrees to Fachrizal, who is more likely to interpret abuse as an act of misuse. While the term "blasphemy," according to Riries WU, is an act that is insulting and disparaging from a religion. ${ }^{22}$

Based on various law policies above, the actions taken by several people in Indonesia who are allegedly violating/deviating from the main points of the relevant religious teachings can be criminalized. This is like what happened in the case of Lia Eden, ${ }^{23}$ Yusman Roy, ${ }^{24}{ }_{-}$Ahmad Mushaddeq, ${ }^{25}{ }_{-}$Ahmadiyya ${ }^{26}{ }_{\text {, }}$, and others.

Besides, it should be noted that deviations from the basic teachings of religion do not only occur in Islam, as in the case have mentioned above. The PAA case also affects Christianity. An example is the case of Mangapin Sibuea, the leader of the "PondokNabi" sect in Bandung, who was reported to the authorities by Christian worshipers because he was considered to have committed a PAA crime because Mangapin Sibuea and his congregants carried out unusual religious activities. The arrest of Mangapin Sibuea occurred when he and 283 members of his congregation gathered at his home in Bale Endah, Bandung. They gathered in order to

\footnotetext{
${ }^{22}$ Riries Widhi Utomo. Analisa Hukum Pidana..., Page 15.
}

${ }^{23}$ Mengaku sebagai Malaikat Jibril. Berkali-kali dipidana penjara karena melakukan tindak
pidana http://news.detik.com/read/2008/12/15/092620/1053613/10/liku-liku-lia-eden-dan-kasus-hukum.

Accesed on March 14,2020

${ }^{24}$ Merupakan pimpinan ponpes Ngaji Lelaku, Lawang Malang. Mengajarkan praktek ibadah shalat dengan dua bahasa. Divonis 2 tahun penjara. Namun tidak terbukti melakukan tindak pidana PAA. Lihat http://news.detik.com/read/2006/11/14/145236/707874/10/ustad-yusman-roy-bebas-tetapajarkan-salat-dua-bahasa?nd992203605. Accesed on March 14, 2020

\footnotetext{
${ }^{25}$ Mengaku sebagai Nabi. Dituntut oleh Jaksa 4 tahun penjara saat sidang di PN Jakarta Selatan. http://news.liputan6.com/read/157298/mushaddeq-dituntut-empat-tahun-penjara. Accesed on March 14,2020
}

\footnotetext{
${ }^{26} J a m a a h$ Ahmadiyah mengakui bahwa Mirza Ghulam Ahmad sebagai Nabi.
} 
wait for the coming of doomsday, which is believed to be coming soon. Mangapin believes that on November 10, 2003, there will be an apocalypse. With this activity automatically contrary to Christian belief in general, and finally,this activity was reported by local Christian religious leaders. 27

From Law No. 1 / PNPS / 1965 above, it can be seen that PAA criminal acts are treated very differently when compared to other criminal acts such as theft, murder and so on. PAA criminal activity requires and involves external parties from ordinary law enforcement officers (Police and Prosecutors' Office). Because the legal object of the case handled can be in the form of organization/group/ sect of faithand also the nature of belief, which requires competent experts in their fields. Institutions directly related to PAA criminal cases are the Ministry of Religion and the Ministry of Home Affairs. The functions of each of these state institutions can be seen in the following chart:

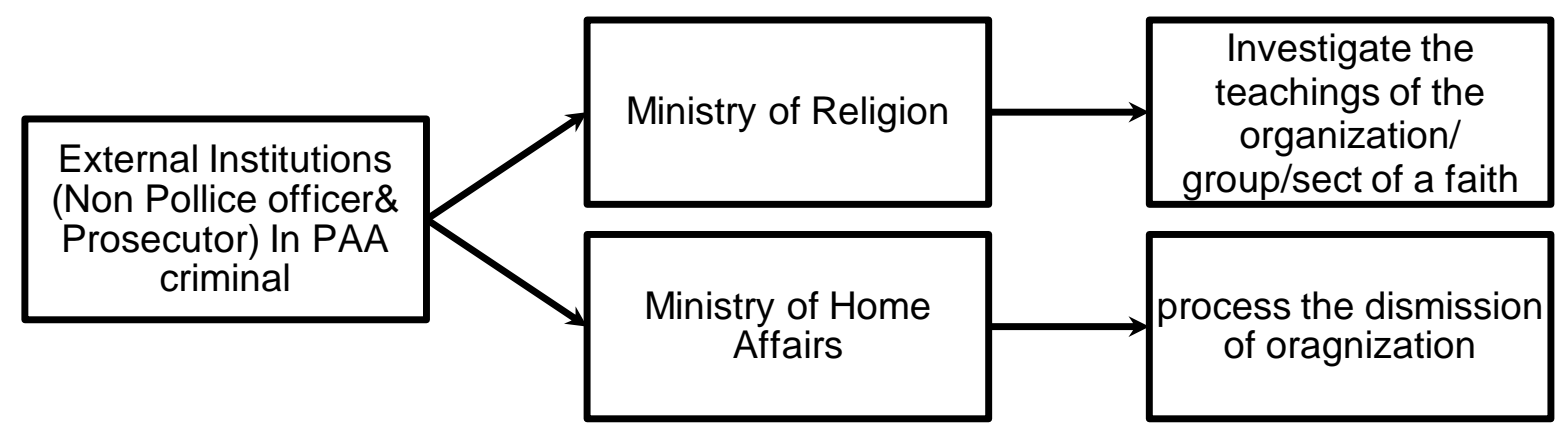

4. The Effectiveness of Criminal Law Policy towards Criminal of Religious Abuse and Blasphemy in Indonesia

As mentioned before, that law policy as social controlcan be assessed its effectiveness through several parameters. Each parameter assessed has a different level of effectiveness influenced by many factors.

a. Law or Legislation

${ }^{27}$ Mangapin Sibuea dituntut 3 (tiga) tahun penjara oleh Jaksa yang kemudian oleh Hakim divonis 2 (dua) tahun penjara. Lihat Randy A. Adare. Delik Penodaan Agama Ditinjau dari Sudut Pandang Hukum Pidana di Indonesia. Jurnal Lex Et Societatis. Vol. 1 No. 1, 2013, Page 98-99. 
As one of the success factors of law enforcement is from the law or the legislation itself, public order will be realized if the state as the ruling party has aided in the form of guidelines in realizing the order itself.

Regarding public order in religion, Indonesia, as the rule of law, has a special law that is used for this purpose. As it was written at the beginning, that since the master book that regulates crime in Indonesia (KUHP) did not yet regulate PAA crime, in 1965 the government issued a legal instrument that became a guideline for criminal law enforcement, namely Law No. 1 / PNPS / 1965. With this law, the government's steps to realize public order, especially related to religion,can be realized.

The effectiveness of this law is increasingly tested when during the reform period,this law was proposed by several institutions and individuals ${ }^{28}$ to the Constitutional Court (MK) to be deleted because it is considered to be contrary to the higher law, namely the 1945 Constitution in particular article 29 verse $2 .{ }^{29}$ Nevertheless, their efforts failed because the Constitutional Court did not grant their claim in full. ${ }^{30}$ By this event clearly strengthens the position of legal policy for PPA crime in the realm of law in Indonesia.

b. Law Enforcement

\footnotetext{
${ }^{28}$ There are 7 (seven) institutions and 4 (four) people who submitted Judicial Review to Law No.1 / PNPS / 1965. These institutions include: IMPARSIAL, ELSAM, YLBHI, etc. While the individuals are: KH. Abdurrahman Wahid, Prof. Dr. Musdah Mulia, Prof. M. Dawam Raharjo, KH. Imanul Haq.

${ }^{29}$ This verse reads: "The state guarantees the independence of each citizen to embrace their respective religions and to worship according to their religion and beliefs ". Penalties for persons deemed to have committed PPA crimes, according to the plaintiff, hinder citizens' freedom of worship which the state has guaranteed through this paragraph.

${ }^{30}$ Decision of the Constitutional Court No. Case 140 / PUU-VII / 2009. In a hearing decision is handled by nine (9) Judges of the Constitutional Court and chaired by Mahfud MD, there are different reasons (coccuring oppinion) and a different opinion (desenting opinion) filed by two (2) judges. A different reason was proposed by Judge Harjono who, according to him, although this law had weaknesses, it could not be canceled because there would be a legal vacuum. While different opinions were put forward by Judge Maria Farida Indrati. According to Judge Maria, this Law could have been canceled because of past products, was not in accordance with the 1945 Constitution and there was often arbitrariness in the implementation of the Law.
} 
As executors of law instruments that have been ratified, it is necessary for parties who have sufficient competence and capability to enforce these law instruments. Therefore, the parties in charge of handling a case are always included in the law instrument itself. This is intended to realize law certainty regarding law enforcement of the instrument.

As mentioned earlier, the government, in dealing with PAA criminal offenses, does not depend entirely on conventional law enforcement like other criminal acts. In this case, Law No. 1 / PNPS / 1965 appointed the Ministry of Religion, the Attorney General's Office, and the Ministry of Home Affairs to issue a Joint Decree in order to give warnings and/or prohibitions against PPA crimes.

In addition to the joint issuance of the Joint Decree, the Attorney General's Office has explicitly its own team for law enforcement relating to PPA crimes. The team in question is thePengawasAliranKepercayaanMasyarakat (PAKEM), which means the controller of community faiths and beliefs. This team actually stood before the Act. No. 1 / PNPS / 1965 was signed because this team stood based on Law No. 15 of 1951 concerning the Basic Provisions of the Attorney General's Office of the Republic of Indonesia. ${ }^{31}$ Before being under the Prosecutor's Office, PAKEM was under the Department of Religion. ${ }^{32}$

The existence of PAKEM plays an important role, including that it serves as a material consideration in issuing SKB. This is evident in the Joint Decree (SKB) on the Prohibition of Ahmadiyah. In this Joint Decree, among the factors taken into consideration is that based on monitoring the PAKEM Coordination Team

\footnotetext{
${ }^{31}$ Law No. 15 of 1951 concerning the Basic Provisions of the Attorney General's Office of the Republic of Indonesia Article 2 Verse 3. The verses in this article contain the main tasks of the Prosecutor's Office. Paragraph 3 reads: "supervise the beliefs that can endanger the community and the State".

${ }^{32}$ PAKEM was initially under the Department of Religion which was tasked with new religions, kebatinan / belief groups and their activities. During the colonial period, similar institutions were also formed by the invaders but aimed to quell the peasants' revolt. Agung Dhedy Dwi Handes. Peranan Kejaksaan Dalam Pengawasan Kepercayaan dan Pencegahan Penyalahgunaan dan atau Penodaan Agama Ditinjau dari Perspektif Penegakan Hukum Pidana. Thesis. (Jakarta: University of Indonesia, 2011), page. 96 .
} 
concluded that although there were a number of points ${ }^{33}$. which have been implemented there are still some points that have not been implemented by adherents, members, and/or members of the administrators of the Ahmadiyya Indonesian Jama'at (JAI) so as to disrupt the peace and order of social life. ${ }^{34} \mathrm{By}$ the example above, it is clear that the performance of the PAKEM Team in carrying out its tasks can be considered quite useful.

However, it must be acknowledged that there are some people who have actually sued the PAKEM Team because they are considered as having many weaknesses and proposing to be removed. According to UliParulianSihombing in his book revealed various weaknesses of the PAKEM Team among them in terms of the paradigm of the formation of the PAKEM Team and the constitutionality of the PAKEM Team. In terms of the formation paradigm, UliParulian considers that the PAKEM Team is a colonial legacy, is not in line with democracy, violates the principle of pluralism, and becomes an instrument of authoritarian and repressive power. ${ }^{35}$. While in terms of constitutionality, the PAKEM Team is considered to have a weak legal basis and has authority that is contrary to the constitution. ${ }^{36}$

Although there are sharp criticisms from some people, most of the Indonesian support the existence of this institution. In this case, the author also

\footnotetext{
${ }^{33}$ The Indonesian Ahmadiyya Jama'at (JAI) in a dialogue with the government on January 14, 2008 delivered 12 (twelve) points explanations. This dialogue was held in order to resolve JAl's problems so as not to cause unrest in religious life and disturb the peace and order of social life.

34 Joint Decree (SKB) Minister of Religion, Attorney General, and Minister of Home Affairs regarding Warnings and Orders to Adherents, Members, and / or Members of the Administrators of the Ahmadiyya Indonesian Jama'at (JAI) and Community Members. This decree was signed on June 9, 2008.

${ }^{35}$ Uli Parulian Sihombing. Menggugat BAKORPAKEM (Kajian Hukum Terhadap Pengawasan Agama dan Kepercayaan di Indonesia) (Jakarta: The Indonesian Legal Resource Center, 2008), pp. 73-82.

${ }^{36}$ Uli Parulian Sihombing. Menggugat BAKORPAKEM., pp. 82-95.
} 
supports the existence of PAKEM because many things are essential, including in the framework of preventing PPA crime itself.

\section{c. Facilities that Support Law Enforcement}

Facilities that support law enforcement, especially the prevention of PPA crime, are sufficient facilities and supporting facilities in the form of physical and non-physical facilities such as Human Resources (HR).

Physical facilities in supporting law enforcement efforts in Indonesia are currently considered quite adequate given the existence of law enforcement institutions that are widespread in all regions of Indonesia.

\section{d. Community Law Awareness}

As mentioned earlier, the function of law on society of which is social control. Through this social control, community life is expected to be good with fellow citizens or the community with the government.

In addition, there is a growing paradigm that the law, along with its interactions with social change, will experience changes and others. In his bookSaifullah writes that:

"hukum melayani kebutuhan masyarakat,agar supaya hukum itu tidak akan menjadi ketinggalan oleh karena lajunya perkembangan masyarakat."37

Translations:

"The law serves the needs of the community, so that the law will not be left behind due to the rapid development of society."

Two things are explained above; if related to the issuance of Law No. 1 / PNPS / 1965, then there is a match. On the one hand, this law structured in order to create religious order in communities, on the other hand, also to respond to the PPA actions that occur in society.

${ }^{37}$ Saifullah. Refleksi Sosiologi Hukum . (Bandung: Refika Aditama, 2010), page. 31 
The government's response in this matter is that efforts to bring order/control of PPA crimes are also directly proportional to what the community does as a manifestation of their law awareness. Law awareness of the community in maintaining the purity of the teachings and the 'dignity' of their religion is seen with community actions when looking at their follow-PPA in their neighborhood. Dialogues toparties which carry out PPA acts voluntarily they do without involving law enforcement authorities. If the dialogue is deemed unsuccessful, then the community will report this PPA action to the authorities. These things have often been done by the community, as happened in the case of Ahmadiyah, Shia, and others.

In addition, community awareness of the law is also accompanied by religious leaders. In this case, Islam, as the majority religion, has an institution that is considered competent in assessing the teachings of a sect, namely the Indonesian Ulama Council (MUI). MUI's support for community efforts as well as religious responsibilities relating to PPA actions is manifested in the form of fatwas and guidelines regarding heretical sect criteria. MUI's Fatwa issued is the MUI Fatwa East Java province who decided that the Shia are a deviant sect. ${ }^{38}$ As for the guidelines for deviant sect criteria, MUI has issued 10 (ten) criteria for those that are considered deviant. $^{39}$

${ }^{38} \mathrm{MUI}$ Fatwa Prov. East Java No. Kep-01 / SKF-MUI / JTM / I / 2012 concerning Misguided Shia Teachings. This fatwa was decided at the MUI asswmbly on January 21, 2012 in Surabaya after the riots that occurred in Sampang, Madura between Sunni Muslims (Majority) and Shia followers led by TajulMuluk. In this fatwa it was decided that Shia is a deviant and is misleading.

\footnotetext{
${ }^{39}$ Among the 10 criteria are: a) denying one of the Pillars of Islam or the Pillars of Faith, b) Believing the revelation after the Qur'an, c) denying the truth and authenticity of the Qur'an, d) denying the Hadith of the Prophet SAW as a source of Islamic teachings, e) Denying the Prophet Muhammad as the last Prophet, f) Disbelieving fellow Muslims without the shari'a arguments. Amruddin A. Fikri. 10 (Ten) MUI Version Fault Criteria (An Assessment Standard). Paper presented at the seminar on "BahayaAliranSesat (The Danger of Deviant Sect)" in the context of the introduction of study and education programs (PPSP) Bogor Chemical Analyst Academy Students, Monday, 15 August (Bogor: MUI, 2011), pp . 1-6.
} 
However, it should be noted that community awareness of the dangers of deviant sect/faith that violates the law is sometimes not accompanied by other law awareness. This is due to the frequent occurrence of clashes, riots, destruction of facilities belonging to others, and the like when the act of dissolving these deviant sects. By the anarchist actions, it will cause counterproductive to law enforcement and awareness (read: awareness of followers of the deviant sect to return to the right path). Even by many parties, anarchist actions can be assessed with a human rights violation. Among the human rights violations resulting from these acts of violence were: a) murders outside legal procedures, b) forced evictions and c) violations of the right to education. ${ }^{40}$

By these acts of violence committed by the community, the authors consider that the effectiveness of the law, when it is viewed by law awareness among the community has less value compared to the value of the effective parameters of the previous law.

\section{e. Culture}

In terminology, culture is defined as the result of human activity and creation (reason) as beliefs, arts, and customs. ${ }^{41}$ Satjipto Rahardjo, as quoted by Hartoyo, sees the law culture as the basis for the implementation or not of positive law in the community, because the implementation of positive law is mostly determined by the attitudes, views, and values they live. ${ }^{42}$ Concerning the effectiveness of criminal law policies on PPA crime, then in this Beragama, Berkeyakinan dan Beribadah di Indonesia. (Jakarta: Solidaritas Perempuan and KONTRAS, 2014), pp.65-68 .

${ }^{41}$ Offline Indonesian Dictionary (KBBI) version 1.5

${ }^{42}$ Hartoyo. Legal Culture in Implementing Government Policy Against Pharmacy Management Requirements in Semarang City. Thesis (Semarang: Uni version of Diponegoro, 2007), p . 28 
parameter, it is seen whether the culture in the Indonesian community supports the implementation of the law policy.

As known, the PPA's actions for Indonesian who have a religious culture are really contradictory because this action can damage the peace and order of the people in religion. The term religious is the author does not stop at the understanding of peace and order in worship, butthe author broadens the understanding that peace and order in religion also include at the level of maintaining the purity of teachings believed by the adherents of the religion itself.

The actions of a group of people like Ahmadiyah, who claimed Mirza Ghulam Ahmad as a Prophet certainly hurt the feelings of Muslims in Indonesia who believed there was no Prophet after the death of the Prophet Muhammad SAW. The spirit of maintaining the purity of the teachings of Islam in the community was finally realized by rejecting the teachings of Ahmadiyah to develop in Indonesia.

So if there is a government effort in order to deal with the problems of this course of PPA action by the communityis supported due in accordance with the values of the culture (maintaining peace and order of religion) in Indonesia.

\section{CONCLUSIONS AND SUGgESTIONS}

From some of the above explanations, the following conclusions can be drawn:

1. In preventing crime in the form of religious abuse and or blasphemy (PPA), the government issued a legal policy in the form of ratification of Law No. 1 PNPS of 1965 concerning the Prevention of Abuse and or Blasphemy of Religion. In this law, PPA criminal acts are divided into 2, religious abuse offenses, and antireligious offenses.

2. The effectiveness of criminal law policies on PPA crime based on parameters offered by Satjipto Rahardjois considered very effective. However, there are 
deficiencies in the law awareness factor among the community, which in the practice of law enforcement often results in acts of anarchism that violate other law instruments.

Considering there are still deficiencies in the effectiveness of law policies related to religious abuse and blasphemy (PPA) crime, the authors propose the following suggestions:

1. The need for religious leaders to increase efforts to educate the community about religious knowledge ( tafaqquh fi diin ) because it is not uncommon for religious abuse and blasphemy(PPA) actions to be carried out by religious adherents themselves.

2. The need to increase dialogue between religious leaders so that harmony among religions in this plural nation is increasingly intertwined.

3. The need for alertness and firmness of the authorities to prevent, detect, and take action against the perpetrators of religious abuse and blasphemy(PPA) acts due to the development of religious abuse and blasphemy (PPA) criminal technology has alsoexpanded to the cyberspace. 


\section{REFERENCES}

\section{Books and Journals Article}

Aan Andrianih. Efektivitas Undang-Undang No. 1 Tahun 1965 tentang Pencegahan Penyalahgunaan dan Penodaan Agama terhadap Kerukunan Beragama. Thesis. Jakarta: University of Indonesia, 2012.

Agung Dhedy Dwi Handes. Peranan Kejaksaan Dalam Pengawasan Kepercayaan dan Pencegahan Penyalahgunaan dan atau Penodaan Agama Ditinjau dari Perspektif Penegakan Hukum Pidana. Thesis. Jakarta: University of Indonesia, 2011.

Andi Hamzah. Terminologi Hukum Pidana. Jakarta: Sinar Gragika. 2013.

Barda Nawawi Arief, Bunga Rampai Kebijakan Hukum Pidana dalam Saiful Abdullah. Kebijakan Hukum Pidana (Penal) dan Non Hukum Pidana (Non Penal) dalam Menanggulangi Aliran Sesat. Thesis. Semarang :University of Diponegoro, 2008.

Fachrizal Afandi. PAKEM: Salah Satu Upaya Negara dalam Melindungi Agama. Journal Al-Qanun. Vol. 12 No. 2, 2009, Page 489-490.

Hartoyo. LegalCulture in Implementing Government Policy Against Pharmacy Management Requirements in Semarang City. Thesis, Semarang: Uni version of Diponegoro, 2007.

Henny Nuraeny, Tindak Pidana Perdagangan Orang: Kebijakan Hukum Pidana dan Pencegahannya, Jakarta: Sinar Grafika, 2013

Indonesia Dictionary (KBBI) Offline versi 1.5

Randy A. Adare. Delik Penodaan Agama Ditinjau dari Sudut Pandang Hukum Pidana di Indonesia. Jurnal Lex Et Societatis. Vol. 1 No. 1, 2013.

Riries Widhi Utomo. Analisa Hukum Pidana Terhadap Tindak Pidana Penistaan Agama Di Indonesia (Kasus Penistaan Agama Pendeta Antonius Rechmon Bawengan Di Temanggung Jawa Tengah). Semarang: IKIP PGRI, 2014.

Saifullah. Refleksi Sosiologi Hukum . (Bandung: Refika Aditama, 2010), page. 31

Soerjono Soekanto. Faktor-Faktor yang Mempengaruhi Penegakan Hukum dalam Imam Sukadi. Matinya Hukum Dalam Proses PenegakanHukum di Indonesia. Jurnal Risalah Hukum. Vol. 7 No. 1, 2011. 
Uli Parulian Sihombing. Menggugat BAKORPAKEM (Kajian Hukum Terhadap Pengawasan Agama dan Kepercayaan di Indonesia), Jakarta: The Indonesian Legal Resource Center, 2008. . Pelanggaran HAM dan Pelanggaran HAM Berat dalam Kasus-Kasus Kebebasan Beragama, Berkeyakinan dan Beribadah di Indonesia. Jakarta: Solidaritas Perempuan and KONTRAS, 2014.

Internet Sources

http://news.detik.com/

http://news.liputan6.com/ 